\title{
Bacterial productivity and benthic standing stocks in a tropical coastal embayment
}

\author{
J. A. Hansen ${ }^{1}$, D. M. Alongi ${ }^{2}$ \\ ${ }^{1}$ School of Biological Sciences (A12), University of Sydney, Sydney, New South Wales 2006, Australia \\ ${ }^{2}$ Australian Institute of Marine Science, PMB No. 3, Townsville M. C., Queensland 4810, Australia
}

\begin{abstract}
Variations in bacterial productivity and microbial and meiofaunal standing stocks were examined in mud, muddy sand and sand sediments of a tropical shallow coastal embayment (Bowling Green Bay) in northeastern Australia. Bacterial densities ranged from 0.4 to $7.0 \times 10^{8}$ cells $\mathrm{g}^{-1}$ dry weight of sediment and were highest in spring and early summer, correlating positively with organic C and total $\mathrm{N}$, and negatively with sediment grain size. Bacterial productivity (range: 32 to $1115 \mathrm{mgC} \mathrm{m}^{-2}$ $\left.\mathrm{d}^{-1}\right)$ and specific growth rates $\left(\mu ; 0.02\right.$ to $\left.3.6 \mathrm{~d}^{-1}\right)$ did not vary with sediment type or correlate with organic C or total $\mathrm{N}$, but were highest in late summer, correlating with sediment temperature. Densities of ciliates (range: undetectable to $393 \mathrm{cells}^{-3}$ ) and large $(>20 \mu \mathrm{m})$ flagellates (range: undetectable to 371 cells $\mathrm{cm}^{-3}$ ) were low and exhibited no clear seasonal or sediment-type patterns. Total meiofaunal densities ranged from 60 to 608 ind $10 \mathrm{~cm}^{-2}$ and did not exhibit seasonal changes; only harpacticoid copepod densities varied with sediment type. Low rates of organic input from adjacent river and water column production are cited as the main causes for the generally low bacterial, protozoan and meiofaunal densities. Bacterial production rates and microbial, meiofaunal, organic $\mathrm{C}$ and $\mathrm{N}$ standing stocks were several times lower in the bay compared with the benthos of a nearby coastal area (Missionary Bay) which receives large inputs of mangrove detritus. The high specific growth rates of bacteria in Bowling Green Bay sediments suggest that the bulk of the flora is metabolically active, probably due, in part, to the continually warm $\left(20\right.$ to $\left.32^{\circ} \mathrm{C}\right)$ sediment temperatures and to enhanced release of porewater nutrients via frequent episodes of wind-driven, sediment resuspension.
\end{abstract}

\section{INTRODUCTION}

Benthic microbial and meiofaunal communities and metabolic activity have been studied in numerous temperate coastal systems along with environmental parameters which could potentially affect them. Factors which have been found to relate to the distribution and activity of microbial and meiofaunal communities include physical characteristics such as temperature or sediment type (McIntyre 1969, Griffiths et al. 1978), chemical characteristics such as organic matter concentrations (Meyer-Reil 1983, 1987) and biological processes such as grazing (Tietjen 1980, but see also Montagna et al. 1983).

Benthic communities have been examined in tropical inshore regions (e.g. McIntyre 1968), but most investigations have focussed on the distribution and abundances of meiobenthic and macroinfaunal communities in predominantly muddy sediments, particularly along the Indian coastline (e.g. Ansari et al. 1982). Most of these tropical subtidal regions border mangroves, coral reefs and seagrass beds, but rarely have such investigations examined more than a few sampling sites for more than one season.

Even more uncommon is information on the distribution and abundances of microbial communities, namely bacterial and protozoan populations, and on rates of bacterial productivity and growth in tropical subtidal sediments. A large proportion of studies which have quantified benthic bacterial populations in the tropics have utilized a variety of plate-counting techniques (e.g. Nair \& Bharathi 1980) which provide severe underestimates of true bacterial abundances. Estimates of free-living protozoan densities (namely ciliates and flagellates) have likewise, until recently, been rare due mainly to problems in extracting the organisms from fine substrates and detrital debris (Alongi 1986). Primarily for these reasons, studies which have simultaneously examined bacterial, protozoan and larger benthic communities have been few, even in temperate regions.

In this study, we examined seasonal variations in 
microbial and meiofaunal standing stocks, bacterial productivity and growth rates in mud, muddy sand and sand sediments within Bowling Green Bay (hereafter BGB), a tropical coastal embayment in northeastern Australia. This bay has been characterised as a low productivity environment (Gillan \& Sandstrom 1985, Ullman \& Sandstrom 1987). We compare this information with similar data (Alongi et al. 1989, Alongi 1990) obtained from a nearby (175 km north) coastal area (Missionary Bay off Hinchinbrook Island; Fig. 1A) which, in contrast to BGB, receives large quantities of outwelled mangrove detritus (Robertson et al. 1988).

\section{MATERIALS AND METHODS}

Bowling Green Bay is a shallow $(<10 \mathrm{~m})$ embayment within the central Great Barrier Reef province and is located ca $50 \mathrm{~km}$ southeast of the city of Townsville in Queensland, Australia (Fig. 1A). The bay is bordered by sand flats, chenier dunes and mangrove forests. Geological and hydrographic conditions within the embayment have been studied by Belperio (1983) and Wolanski \& Jones (1981), respectively.

Sediments from a 12 station grid (Fig. 1B) were sampled seasonally using a frame-supported Van Veen grab $\left(0.125 \mathrm{~m}^{2}\right.$ surface area). One or two grabs per station were subsampled for microbial, sedimentologi- $\mathrm{cal}$ and meiofaunal analyses by inserting replicate $(\mathrm{n}=$ 1 to 5 ) syringes (with the luer ends removed) to a depth of $1 \mathrm{~cm}$ (up to $5 \mathrm{~cm}$ for meiofauna) and processed as described below.

To determine bacterial numbers, $1 \mathrm{~cm}$ deep cores were collected with $2 \mathrm{ml}$ cut-off syringes $\left(0.64 \mathrm{~cm}^{2}\right.$ surface area) and preserved in $15 \mathrm{ml}$ of $10 \%$ formalin in $0.22 \mu \mathrm{m}$ Millipore-filtered seawater. Samples were homogenized for $5 \mathrm{~min}$ with an additional $10 \mathrm{ml}$ $0.001 \%$ Tween 80 in seawater to disperse clay aggregates (Hansen et al. 1987, Alongi 1988). Bacterial numbers were estimated from diluted and stained samples by epifluorescence microscopy (Hobbie et al. 1977). Fourteen fields per duplicate slide were counted for each sample on a Leitz Ortholux II compound microscope with appropriate fluorescence attachments. Counts were corrected for recovery of attached cells using the cumulative yield method described by Ellery \& Schleyer (1984). Cell biovolumes were determined microscopically. The average size of bacteria in these sediments was $0.2 \mu \mathrm{m}^{3}$ and a value of $1.25 \times 10^{-23} \mathrm{gC}$ $\mu \mathrm{m}^{-3}$ was used to convert cell volume to carbon (Hansen et al. 1987).

Bacterial production rates were calculated from the rate of tritiated thymidine incorporation into DNA as described by Pollard (1987). Separate experiments were conducted to determine that the incubation time (10 $\mathrm{min}$ ) was within the linear portion of the incorpora-

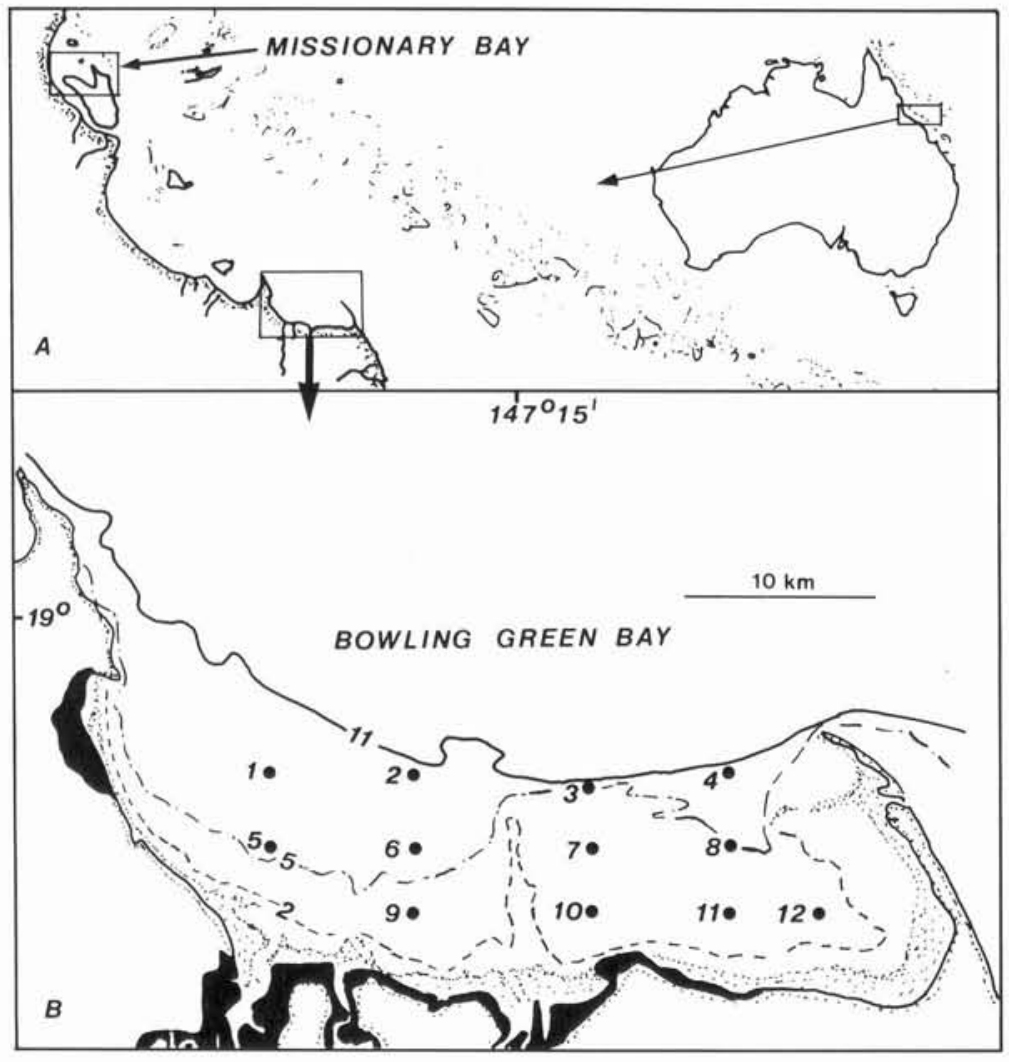

Fig. 1. (A) Locations of Bowling Green Bay and Missionary Bay in relation to the northeastern coast of Australia; (B) sampling stations in Bowling Green Bay. Depth contours are in metres. Blackened areas are mangrove forests 
tion curve. Isotope dilution curves showed that addition of $5 \mathrm{nmol}$ of thymidine per sample was sufficient to overcome any dilution effects (Pollard \& Moriarty 1984). To determine rates of thymidine uptake, replicate $0.2 \mathrm{~g}$ samples of sediment were obtained using 1 $\mathrm{ml}$ syringe-corers and were placed into separate test tubes. Each sample received $45 \mu \mathrm{Ci}$ [methyl- ${ }^{3} \mathrm{H}$ ] thymidine (specific activity: $9 \mathrm{Ci} \mathrm{mmol}^{-1}$ ) and was incubated at in situ temperatures. Sediments were unavoidably disturbed but previous studies have indicated that disturbance effects are not evident for incubation times $<15$ min (Findlay et al. 1985, Moriarty \& Pollard 1990). Bacterial production was calculated using a conversion factor of $2.0 \times 10^{18}$ cells dividing per mole thymidine incorporated (Moriarty 1986) and the above-cited carbon conversion factor. Specific growth rate, $\mu\left(\mathrm{d}^{-1}\right)$ was calculated by dividing production estimates by standing crop (Alongi 1988).

Protozoa were extracted from replicate cores $(1.1 \mathrm{~cm}$ inner diameter, $1 \mathrm{~cm}$ deep) using the silica gel Percoll (Alongi 1986). Each core was centrifuged at low speed $(490 \times \mathrm{g})$ for $20 \mathrm{~min}$ in a $30 \mathrm{ml}$ centrifuge tube containing $10 \mathrm{ml}$ of a Percoll-sorbitol mixture. The procedure was repeated 3 times. Ciliates, large $(>20 \mu \mathrm{m})$ flagellates and soft-bodied meiofauna in the supernatant were counted in a petri dish with the glass bottom lined into $1 \mathrm{~cm}^{2}$ grids.

Hard-bodied (chitinous) meiofauna were extracted from replicate cores $\left(6.6 \mathrm{~cm}^{2}\right.$ surface area) to a depth of $5 \mathrm{~cm}$. Each core was preserved in a 1:500 (v/v) mixture of Rose Bengal $\left(0.5 \mathrm{~g} \mathrm{l}^{-1}\right)$ in buffered seawater formalin $(5 \%)$. In the laboratory, sediments were passed through a set of 2 sieves, the top one with a mesh opening of $500 \mu \mathrm{m}$ and the bottom screen with a mesh size of $45 \mu \mathrm{m}$. Animals retained on the $45 \mu \mathrm{m}$ mesh were enumerated under a dissecting microscope.

Sediment granulometry and organic carbon and nitrogen were measured from replicate cores taken to a depth of $2 \mathrm{~cm}$. All samples were immediately frozen onboard ship until analyzed in the laboratory. Grain size analysis of sediments followed methods described in Folk (1974). Percent silt and clay were estimated by sieve and pipette analysis. The sand fraction was drysifted and weighed to determine particle-size distribution. Redox potential (Eh) was measured by inserting a combination PRFO redox electrode $5 \mathrm{~cm}$ into the sediment at each station and allowing to equilibrate for 10 min before readings were taken using a TPS Model $\mathrm{LC} 80 \mathrm{pH} / \mathrm{mV}$ meter. Organic carbon and total nitrogen concentrations ( $\%$ by sediment dry weight) were determined from milled, freeze-dried cores. Organic carbon was measured on a Beckman TOCAMASTER Total Carbon Analyser. Total nitrogen was measured in the same samples on a LECO model $600 \mathrm{CHN}$ Analyser.

Differences in microbial and sediment factors and in meiofaunal densities among stations and seasons were tested using standard 2-level analysis of variance (Sokal \& Rohlf 1969). Each analysis of variance was followed by a Student-Newman-Keuls (SNK) multiple comparisons test to determine which factors were significantly greater or less than others (2-tailed test). Bacterial productivity and microbial and meiofaunal densities were $\log (x+1)$-transformed and sediment factors were arcsine-transformed when homogeneity of variance was rejected by a prior F $_{\text {MAX }}$ test. Relationships among microbial and meiofaunal factors and with

Table 1. Particle size and organic content in Bowling Green Bay, inner Queensland continental shelf. Values depict grand means (March to November 1985)

\begin{tabular}{|c|c|c|c|c|c|c|c|}
\hline Station & $\begin{array}{c}\text { Graphic mean } \\
(\varnothing)\end{array}$ & $\begin{array}{c}\text { Redox } \\
\text { potential } \\
\text { (Eh) }\end{array}$ & $\begin{array}{c}\% \\
\text { Gravel- } \\
\text { sand }\end{array}$ & $\begin{array}{c}\% \\
\text { Silt- } \\
\text { clay }\end{array}$ & $\begin{array}{c}\% \\
\text { Organic C } \\
\text { (by dry wt) }\end{array}$ & $\begin{array}{c}\% \\
\text { Total N } \\
\text { (by dry wt) }\end{array}$ & $\begin{array}{c}\text { Atomic } \\
\mathrm{C} / \mathrm{N}\end{array}$ \\
\hline \multicolumn{8}{|l|}{ Mud } \\
\hline 4 & 7.1 fine silt & +113 & 0.4 & 99.6 & 1.1 & 0.10 & 12.9 \\
\hline 6 & 4.8 coarse silt & +122 & 6.8 & 93.2 & 0.9 & 0.08 & 12.8 \\
\hline 8 & 4.1 coarse silt & +89 & 32.4 & 67.6 & 0.8 & 0.07 & 13.3 \\
\hline 9 & 4.3 coarse silt & +138 & 13.0 & 87.0 & 0.7 & 0.06 & 13.7 \\
\hline 10 & 4.0 coarse silt & +137 & 38.7 & 61.3 & 0.6 & 0.05 & 14.0 \\
\hline 11 & 6.3 medium silt & +38 & 1.5 & 98.5 & 1.1 & 0.10 & 13.1 \\
\hline 12 & 6.3 medium silt & +122 & 1.6 & 98.4 & 1.0 & 0.08 & 14.6 \\
\hline \multicolumn{8}{|l|}{ Sand } \\
\hline 3 & 1.3 medium silt & +306 & 88.6 & 11.4 & 0.12 & 0.02 & 6.1 \\
\hline \multicolumn{8}{|c|}{ Muddy sand } \\
\hline 1 & 3.8 very fine sand & +239 & 62.2 & 37.8 & 0.30 & 0.03 & 12.5 \\
\hline 2 & 3.6 very fine sand & +234 & 63.0 & 37.0 & 0.45 & 0.04 & 12.5 \\
\hline 5 & 3.9 very fine sand & +289 & 52.1 & 47.9 & 0.62 & 0.05 & 13.7 \\
\hline 7 & 3.9 very fine sand & +237 & 53.9 & 46.1 & 0.42 & 0.02 & 16.3 \\
\hline
\end{tabular}


sediment characteristics were examined across stations and sampling intervals using Pearson's productmoment correlation analysis (Sokal \& Rohlf 1969).

\section{RESULTS}

\section{Edaphic factors}

Bowling Green Bay is dominated by areas of mud (fine to coarse silt) and very fine sand (Table 1). Organic carbon and total nitrogen concentrations were low, ranging from 0.12 to $1.1 \%$ and from 0.02 to $0.10 \%$, respectively, and were significantly $(p<0.01)$ greater at the mud stations than at the sandier sites. Grain size and nutrient concentrations did not change $(p>0.05)$ significantly at each station over time. Sediment temperatures varied little among stations at each sampling period (generally $\leq 1^{\circ} \mathrm{C}$ ) and ranged seasonally from 20 to $32^{\circ} \mathrm{C}$ (Table $2 \mathrm{~A}$ ).

\section{Effects of sediment type and season}

Bacterial densities ranged from 0.4 to $7.0 \times 10^{8}$ cells $\mathrm{g}^{-1}$ dry wt (Table 2A) and exhibited significant seásonal and site variations (Table $2 \mathrm{~B}, \mathrm{C}$ ) and interactive effects. The SNK tests indicated that densities were generally highest during the warmest months and at the muddiest sites. Cell counts correlated significantly with sediment temperature $(\mathrm{r}=+0.49 ; \mathrm{p}<0.05)$ and grain size $(\mathrm{r}=-0.62 ; \mathrm{p}<0.01)$. The significant interac-

Table 2. Variations in bacterial densities (cells $\mathrm{g}^{-1}$ dry wt sediment) in Bowling Green Bay sediments. Values depict means \pm 1 SD over 0 to $1 \mathrm{~cm}$ depth. LSu: late summer (Jan 1985); EAu: early autumn (Mar 1985); LAu: late autumn (May 1985); W: winter (Jul 1985); Sp: spring (Sep 1985); ESu: early summer (Nov 1985)

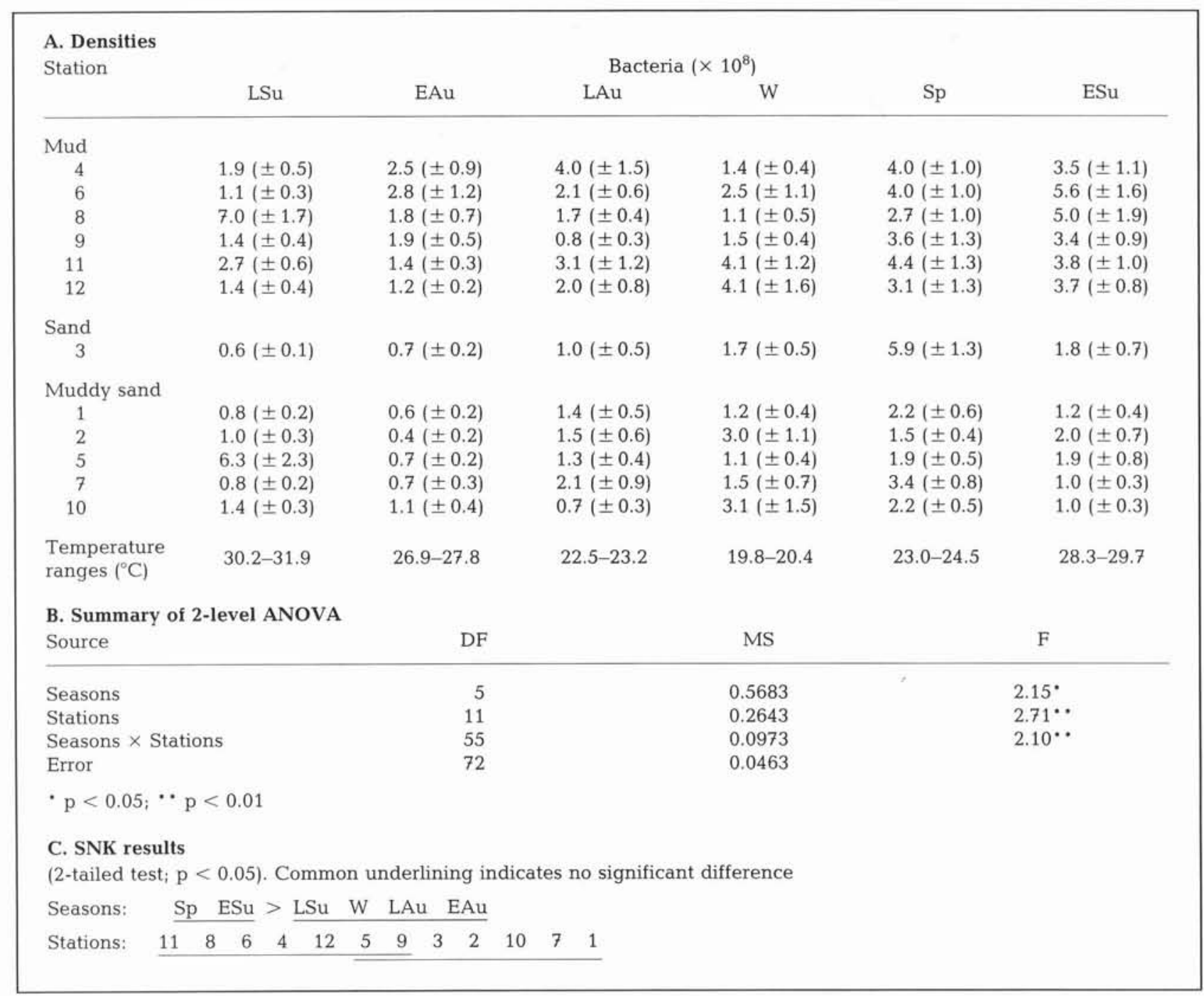


tion term probably reflects density differences among sites at different sampling periods (e.g. densities at Stn 4 were not always greater than those at Stn 3 at each sampling period; see Table $2 \mathrm{~A}$ ).

Bacterial productivity and specific growth rates $(\mu)$ ranged from 32 to $1115 \mathrm{mg} \mathrm{C} \mathrm{m}^{-2} \mathrm{~d}^{-1}$ and from 0.02 to $3.6 \mathrm{~d}^{-1}$, respectively (Tables $3 \mathrm{~A} \& 4 \mathrm{~A}$ ). Although there were significant interaction effects of bacterial production, for both parameters seasonality accounted for $77.6 \%$ (production) and $54.8 \%$ (growth rates) of the total variance, respectively (Tables 3B \& 4B). Site differences were significant for bacterial production, but minor (Table $3 \mathrm{C}$ ), accounting for $<10 \%$ of the variance of both production and growth rates. Both productivity $(\mathrm{r}=+0.63)$ and specific growth rates $(\mathrm{r}=$ $+0.42)$ correlated significantly $(\mathrm{p}<0.05)$ with sediment temperature.

Ciliate densities ranged from undetectable to 393 cells $\mathrm{cm}^{-3}(\overline{\mathrm{x}}=63$; Table $5 \mathrm{~A})$. The very large interaction term (Table 5B) indicates large and inconsistent variations in densities among stations and seasons with no clear temporal and spatial patterns (SNK tests were therefore not performed). Densities of large $(>20 \mu \mathrm{m})$ flagellates ranged from undetectable to 371 cells $\mathrm{cm}^{-3}$ $(\overline{\mathrm{x}}=56$; Table $5 \mathrm{~A})$. The lack of significant seasonality and station differences, and a significant interaction term, reflects generally low and random density patterns (Table 5B).

Total meiofaunal densities ranged from 60 to 608 individuals $10 \mathrm{~cm}^{-2}(\overline{\mathrm{x}}=232$; Table $6 \mathrm{~A})$ and did not exhibit significant seasonal or sediment-type patterns (Table 6B). Nematodes were the most abundant taxon, accounting for 86 to $94 \%$ of total faunal densities. Harpacticoid copepods and turbellarians were the next most abundant taxa, accounting for 1 to $10 \%$ and from 2 to $8 \%$ of total meiofaunal abundances, respectively (data not shown). Of the 3 taxa, only copepods varied with sediment type, being significantly $(p<0.05)$ more abundant in sand ( 4 to 31 ind. $10 \mathrm{~cm}^{-2}$ ) than at the muddier sites ( 1 to 12 ind. $10 \mathrm{~cm}^{-2}$ ). Total meiofaunal

Table 3. Variations in bacterial productivity $\left(\mathrm{mgC} \mathrm{m}^{-2} \mathrm{~d}^{-1}\right)$ in Bowling Green Bay sediments. Values depict means \pm 1 SD over 0 to $1 \mathrm{~cm}$ depth. Seasons as in Table 2

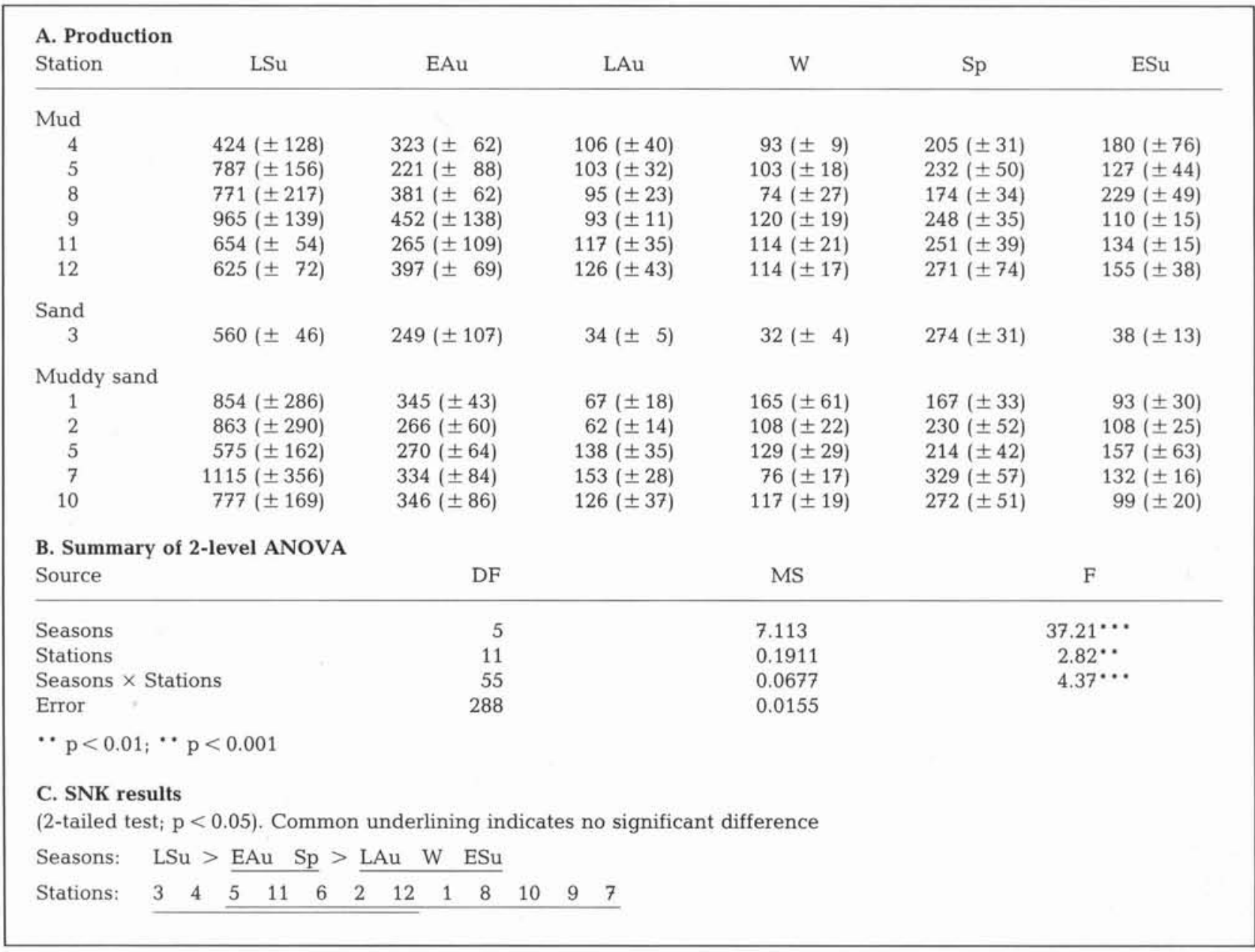


Table 4. Variations in specific growth rates, $\mu\left(\mathrm{d}^{-1}\right)$, in Bowling Green Bay sediments, $\mu$ values $=$ mean production estimates $\div$ mean standing crop. Seasons as in Table 2

\begin{tabular}{|c|c|c|c|c|c|c|c|}
\hline \multicolumn{8}{|c|}{ A. Specific growth rates } \\
\hline Station & LSu & EAu & LAu & W & $\mathrm{Sp}$ & & ESu \\
\hline \multicolumn{8}{|l|}{ Mud } \\
\hline 4 & 1.0 & 0.6 & 0.1 & 0.4 & 0.2 & & 0.3 \\
\hline 6 & 2.3 & 0.4 & 0.1 & 0.2 & 0.3 & & 0.1 \\
\hline 8 & 0.3 & 0.8 & 0.2 & 0.2 & 0.2 & & 0.5 \\
\hline 9 & 2.1 & 0.6 & 0.3 & 0.3 & 1.0 & & 1.0 \\
\hline 11 & 0.7 & 0.7 & 0.2 & 0.1 & 0.2 & & 0.1 \\
\hline 12 & 1.3 & 1.3 & 0.3 & 0.1 & 0.3 & & 0.2 \\
\hline \multicolumn{8}{|l|}{ Sand } \\
\hline 3 & 1.1 & 0.4 & 0.04 & 0.02 & 0.2 & & 0.05 \\
\hline \multicolumn{8}{|c|}{ Muddy sand } \\
\hline 1 & 1.9 & 0.9 & 0.1 & 0.1 & 0.1 & & 0.2 \\
\hline 2 & 1.2 & 1.5 & 0.1 & 0.04 & 0.3 & & 0.1 \\
\hline 5 & 0.2 & 0.7 & 0.2 & 0.2 & 0.2 & & 0.3 \\
\hline 7 & 3.6 & 0.8 & 0.2 & 0.06 & 0.3 & & 0.1 \\
\hline 10 & 1.7 & 0.8 & 0.6 & 0.2 & 0.3 & & 0.2 \\
\hline \multicolumn{8}{|c|}{ B. Summary of 2-level ANOVA ${ }^{a}$} \\
\hline \multicolumn{2}{|c|}{ Source } & \multicolumn{2}{|l|}{ DF } & MS & \multicolumn{3}{|c|}{ F } \\
\hline \multicolumn{2}{|l|}{ Seasons } & \multicolumn{2}{|l|}{5} & 3.09 & \multicolumn{3}{|c|}{$13.79 \cdots$} \\
\hline \multicolumn{2}{|l|}{ Stations } & \multicolumn{2}{|l|}{11} & 0.224 & \multirow{2}{*}{\multicolumn{3}{|c|}{$1.20^{\mathrm{ns}}$}} \\
\hline \multicolumn{2}{|l|}{ Error } & 55 & & 0.186 & & & \\
\hline \multicolumn{8}{|c|}{$\cdots p<0.001 ;$ ns $=$ not significant } \\
\hline \multicolumn{8}{|c|}{$\begin{array}{l}\text { C. SNK results } \\
(2 \text {-tailed test; } \mathrm{p}<0.05) \text {. Common underlining indicates no significant difference }\end{array}$} \\
\hline \multicolumn{8}{|c|}{ Seasons: $\quad$ LSu $>$ EAu $>$ Sp $>$ LAu ESu W } \\
\hline
\end{tabular}

densities did not correlate with any of the microbial or edaphic parameters; only copepods correlated significantly $(\mathrm{p}<0.05)$ with percent sand $(\mathrm{r}=+0.61)$.

\section{DISCUSSION}

Benthic communities in temperate subtidal habitats are greatly affected by seasonal changes in temperature, food resources and by variations in sediment composition (McIntyre 1969, Griffiths et al. 1978, Meyer-Reil 1983, 1987). Our results suggest that the low abundances of microbes and meiofauna in Bowling Green Bay reflect the dominance of hydrodynamic processes (wind-waves, tidal energy) as well as low rates of organic input to this shallow tropical embayment. Bacterial biomass, productivity and specific growth rates were highest during the warmest months of the year, all correlating significantly with sediment temperature. Bacterial production and growth rates were not correlated with organic C or total $\mathrm{N}$, although such a relationship has been observed in other benthic communities (Meyer-Reil 1983, 1987).

Bacterial abundance did not correlate with the abundance of potential predators (protozoans or meiofauna), which is consistent with results found for a temperate coastal sediment (Montagna et al. 1983). Microbial-meiofaunal interactions are likely to be difficult to discern particularly in such a hydrodynamically-controlled environment as Bowling Green Bay. Abundances of predators relative to microbial prey, species composition and rates of nutrient supply are likely to influence the outcome of such interactions. Microflagellates $(<20 \mu \mathrm{m}$ cell size) were not examined, but considering their high densities $\left(>10^{3}\right.$ cells $\left.\mathrm{cm}^{-3}\right)$ in other nearby coastal sediments (Alongi 1990) they may have played a role in fostering the generally high specific growth rates of bacteria observed in the bay.

Lack of seasonality in the protozoan and meiofaunal communities probably reflected the lack of change in 
Table 5. Ciliate and flagellate densities (no. of cells $\mathrm{cm}^{-3}$ ) in Bowling Green Bay sediments. Values depict mean $\pm 1 \mathrm{SD}$ of cells over 0 to $1 \mathrm{~cm}$ depth interval. Seasons as in Table 2

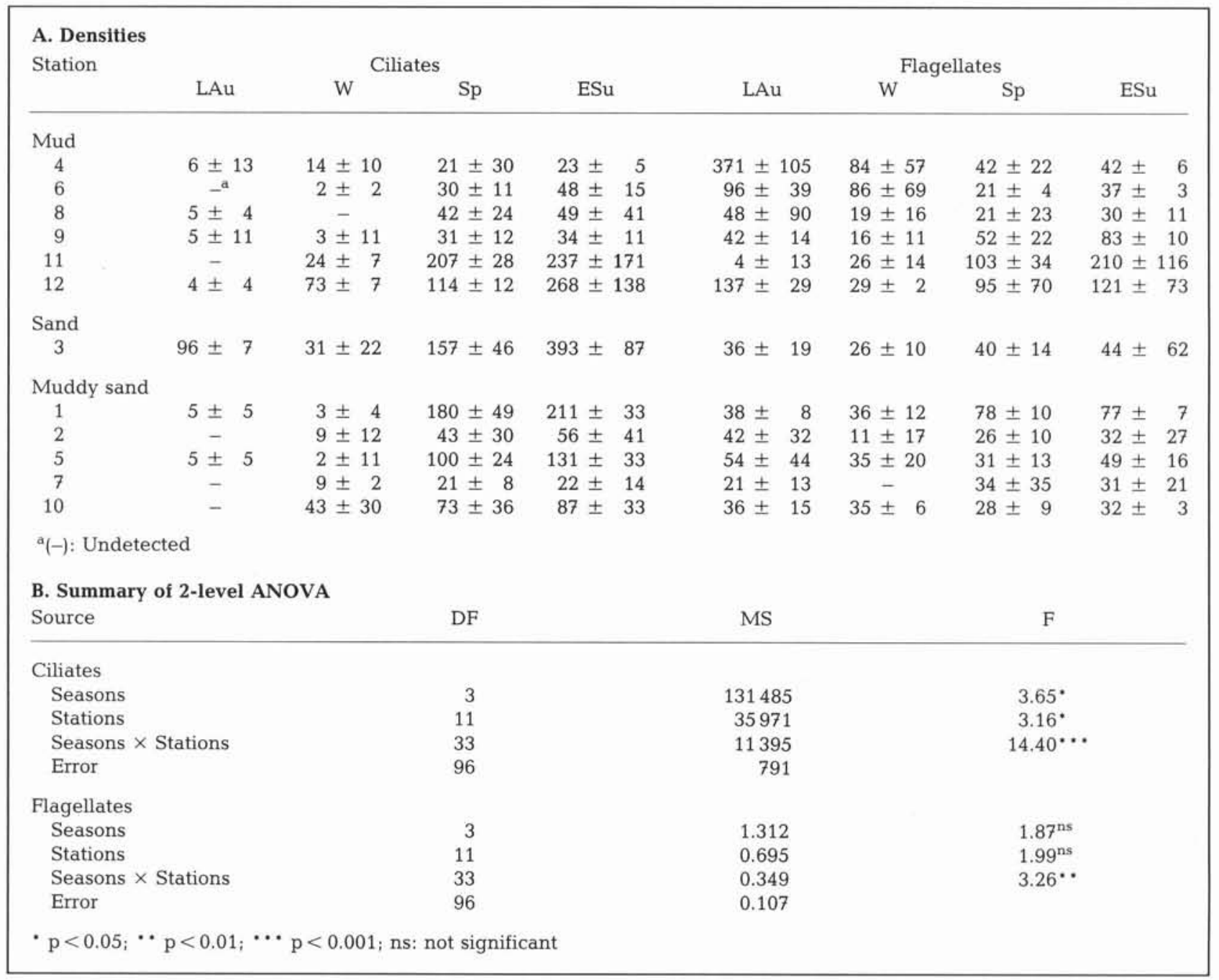

sediment grain size and organic conditions observed during the year. Seasonal changes in the generally warm sediment temperatures $\left(20\right.$ to $\left.32^{\circ} \mathrm{C}\right)$ may have been too narrow to noticeably affect protozoan and meiofaunal reproductive strategies, as previously suggested for tropical macroinvertebrates by Thorson (1957) and Moore (1972). Most of the meiofaunal populations were not strongly affected by sediment type. This is surprising because nematodes and other meiobenthos are usually most abundant in shallow subtidal muddy sand habitats (McIntyre 1969). It is plausible that the influence of sediment type was counteracted by resuspension of sediments, which is frequently observed in the bay (Belperio 1983). In addition, other factors not measured (e.g. microalgae, macrofauna) may have influenced the meiofaunal populations.
Several reasons can be cited for the low faunal densities and organic $C$ and total $N$ concentrations: low benthic primary production, frequent disturbance by sediment resuspension, low rates of organic input from the overlying water column and adjacent rivers, and possible predation by and competition with other benthos. Benthic primary production is not measurable in many parts of Bowling Green Bay. Where it occurs, production is not high (e.g. $102 \mathrm{mgC} \mathrm{m}^{-2} \mathrm{~d}^{-1}$ maximum in summer; Hansen unpubl.). Pelagic production is reasonably high in coastal waters near Bowling Green Bay (48 to $56 \mathrm{mgC} \mathrm{m}^{-3} \mathrm{~d}^{-1}$; Revelante \& Gilmartin 1982) but most of the production is within the $<2 \mu \mathrm{m}$ size fraction, and thus the quantity of dead phytoplankton cells reaching the sediments is probably low. Frequent resuspension of the sediments increases the residence time of the organic matter in the water column 
Table 6. Total meiofaunal densities (no. $10 \mathrm{~cm}^{-2}$ ) in Bowling Green Bay sediments. Values are mean $\pm 1 \mathrm{SD}$ over 0 to $5 \mathrm{~cm}$ depth interval. Seasons as in Table 2

\begin{tabular}{|c|c|c|c|c|c|c|}
\hline \multirow{2}{*}{$\begin{array}{l}\text { A. Densities } \\
\text { Station } \\
\text { Muddy sand }\end{array}$} & \multirow[t]{2}{*}{ EAu } & W & $\mathrm{Sp}$ & $\mathrm{ESu}$ & \multicolumn{2}{|l|}{ LAu } \\
\hline & & & & & & \\
\hline 1 & $193 \pm 22$ & $190 \pm 94$ & $140 \pm 54$ & $342 \pm 86$ & $188 \pm 2$ & 28 \\
\hline 2 & $182 \pm 59$ & $145 \pm 48$ & $95 \pm 30$ & $136 \pm 4$ & $200 \pm$ & 9 \\
\hline 5 & $317 \pm 139$ & $608 \pm 429$ & $345 \pm 39$ & $290 \pm 95$ & $280 \pm 7$ & 73 \\
\hline 7 & $226 \pm 14$ & $220 \pm 30$ & $172 \pm 23$ & $227 \pm 30$ & $238 \pm 2$ & 27 \\
\hline 10 & $204 \pm 20$ & $253 \pm 56$ & $172 \pm 8$ & $430 \pm 189$ & $234 \pm 4$ & 47 \\
\hline \multicolumn{7}{|l|}{ Sand } \\
\hline 3 & $441 \pm 220$ & $518 \pm 375$ & $299 \pm 100$ & $60 \pm 27$ & $227 \pm 1$ & 17 \\
\hline \multicolumn{7}{|l|}{ Mud } \\
\hline 4 & $254 \pm 104$ & $151 \pm 20$ & $75 \pm 11$ & $130 \pm 14$ & $209 \pm 12$ & 28 \\
\hline 6 & $135 \pm 5$ & $299 \pm 98$ & $109 \pm 57$ & $220 \pm 99$ & $151 \pm 1$ & 11 \\
\hline 8 & $181 \pm 101$ & $138 \pm 17$ & $272 \pm 48$ & $222 \pm 8$ & $111 \pm 1$ & 16 \\
\hline 9 & $157 \pm 64$ & $257 \pm 8$ & $403 \pm 360$ & $219 \pm 39$ & $186 \pm 1$ & 16 \\
\hline 11 & $61 \pm 7$ & $190 \pm 27$ & $223 \pm 15$ & $215 \pm 29$ & $81 \pm 4$ & 40 \\
\hline 12 & $303 \pm 92$ & $255 \pm 10$ & $271 \pm 114$ & $218 \pm 102$ & $345 \pm 5$ & 52 \\
\hline \multicolumn{7}{|c|}{ B. Summary of 2-level ANOVA } \\
\hline Source & & DF & & & $\mathrm{F}$ & \\
\hline Seasons & & 4 & & & $0.29^{\text {ns }}$ & \\
\hline Stations & & 11 & & & $1.95^{\mathrm{ns}}$ & \\
\hline Seasons $\times$ Stations & & 44 & & & $1.17^{\mathrm{ns}}$ & \\
\hline Error & & 60 & & & & \\
\hline ns: not significant & & & & & & \\
\hline
\end{tabular}

and may result in sedimented material which is largely refractory due to decomposition by pelagic microheterotrophs (Raine \& Patching 1980, Hopkinson 1985).

A comparison of microbial and meiofaunal densities and nutrient concentrations in Bowling Green Bay with values obtained from the Missionary Bay region offers some support for the influence of low organic input
(Table 7). The Missionary Bay region (Fig. 1A) differs from Bowling Green Bay in that it receives large quantities of mangrove litter outwelled from adjacent forests (Robertson et al. 1988) which are several orders of magnitude larger than mangroves bordering Bowling Green Bay (Galloway 1982). In Missionary Bay sediments, nearly all microbial and meiofaunal values are several times greater than those in Bowling Green Bay.

Table 7. Microbial and meiofaunal comparisons between Bowling Green Bay (BGB) and Missionary Bay (MB), North Queensland, Australia. Values depict means; ranges in parentheses

\begin{tabular}{|lcc|}
\hline & BGB & MB \\
\hline Bacteria & $2.3\left(0.4-7.0 \times 10^{8}\right)$ & $5.9\left(0.5-20.8 \times 10^{10}\right)$ \\
Bacterial production & $273(32-1115)$ & $612(23-1854)$ \\
Specific growth rates & $0.53(0.02-3.6)$ & $0.14(0.004-0.79)$ \\
Ciliates & $0.3(0-393)$ & $157(23-511)$ \\
Flagellates & $56(0-371)$ & $185(40-806)$ \\
Meiofauna & $232(60-608)$ & $497(293-1,193)$ \\
Org. C & $0.7(0.12-1.1)$ & 1.2 \\
Total N & $0.06(0.02-0.10)$ & $0.09(0.22-2.6)$ \\
Water depth $(\mathrm{m})$ & $3-10$ & $4-15$ \\
Source & This study & Alongi et al. (1989); \\
& & Alongi (1990, unpubl.) \\
\hline
\end{tabular}


Bacterial densities are 250× greater in Missionary Bay and rates of productivity are twice as high (Table 7 ). Specific growth rates of bacteria are generally faster in $B G B$, but this difference may be due to methodological problems: Missionary Bay sediments are generally less oxidized than BGB sediments of equivalent grain size and, as thymidine is generally not (or very slowly) taken up by anaerobes (Moriarty 1986), the Missionary Bay growth rates may, in reality, be underestimated. Although both embayments were sampled in different years, it is clear that the higher concentrations of organic $\mathrm{C}$ and $\mathrm{N}$ in Missionary Bay muds and sands reflect greater rates of organic input which support more abundant and productive benthic communities compared to those in Bowling Green Bay.

Two previous studies suggest that the quantity and nutritional availability of sedimentary organic matter in the bay is low, lacking in fresh plankton detritus and microalgae. It may be relatively unreactive due to dilution by refractory terrigenous organic matter (Gillan \& Sandstrom 1985, Ullman \& Sandstrom 1987). In an analysis of extractable lipids and fatty acids in Bowling Green Bay sediments, Gillan \& Sandstrom (1985) found consistently low total fatty acid abundances $\left(\leq 2 \mu \mathrm{g} \mathrm{g}^{-1}\right.$ sediment dry wt). Lipid phosphates were below detection limits. Based on the fatty acid profiles, they concluded that bay sediments are relatively low in algal (and/or cyanobacterial) and bacterial biomass, but potentially rich in protozoan detritus. They estimated an average bacterial cell count in surface bay sediments of $4 \times 10^{7}$ cells g ${ }^{-1}$ dry wt, within the range of our direct count estimates.

Fluxes of dissolved inorganic nutrients from Bowling Green Bay sediments are significantly lower than those reported from temperate sediments (Ullman \& Sandstrom 1987) indicating low reactivity of deposited organic matter. Interestingly, however, a number of cores showed net fluxes into the sediment despite porewater gradients suggesting a net efflux, indicating that nutrients are being rapidly utilized at the sedimentwater interface. Our high specific rates of bacterial growth appear to support this conjecture.

Ullman \& Sandstrom (1987) calculated that resuspension of only the top $1 \mathrm{~cm}$ of sediment in the bay would significantly raise the dissolved inorganic $\mathrm{N}$ concentration at the sediment-water boundary layer, perhaps enough to keep the low density bacterial populations at the sediment surface in an active metabolic state. Thus, high specific growth rates of bacteria in Bowling Green Bay sediments could be maintained by the generally warm and narrow range of sediment temperatures and the enhancement of dissolved nutrients at the sediment surface via frequent sediment resuspension (Wolanski \& Jones 1981, Belperio 1983). Recent experiments (Findlay et al. 1990a, b) indicate that bacterial com- munities in disturbed sediments may shift their metabolic status without a concomitant increase in biomass. This suggests that in benthic habitats such as Bowling Green Bay, disturbed bacteria may undergo increases in metabolic activity which may not necessarily lead to cell division.

Acknowledgements. We thank H. Streiner, H. Sturmey, K. Navin, M. Riddle and P. Dayton for field and laboratory assistance. The Masters and crews of the RV 'Lady Basten' and RV 'The Harry Messel' are thanked for their help. Kim Truscott typed the manuscript. Contribution no. 508 from the Australian Institute of Marine Science.

\section{LITERATURE CITED}

Alongi, D. M. (1986). Quantitative estimates of benthic protozoa in tropical marine systems using silica gel: a comparison of methods. Estuar. coast. Shelf Sci. 23: 443-450

Alongi, D. M. (1988). Microbial-meiofaunal interrelationships in some tropical intertidal sediments. J. mar. Res. 46: 349-365

Alongi, D. M. (1990). Abundances of benthic microfauna in relation to outwelling of mangrove detritus in a tropical coastal region. Mar. Ecol. Prog. Ser. 63: 53-63

Alongi, D. M., Boto, K. G., Tirendi, F. (1989): Effect of exported mangrove litter on bacterial productivity and dissolved organic carbon fluxes in adjacent tropical nearshore sediments. Mar. Ecol. Prog. Ser. 56: 133-144

Ansari, Z. A., Rodrigues, C. L., Chatterji, Pasulekar, A. H. (1982). Distribution of meiobenthos and macrobenthos at the mouth of some rivers of the east coast of India. Indian J. mar. Sci. 11: 341-343

Belperio, A. P. (1983). Terrigenous sedimentation in the Central Great Barrier Reef Lagoon: a model from the Burdekin Region. BMR J. Aust. Geol. Geophys. 8: 179-190

Ellery, W. H., Schleyer, M. H. (1984). Comparison of homogenization and ultrasonification as techniques in extracting attached sedimentary bacteria. Mar. Ecol. Prog. Ser. 15: 247-250

Findlay, R. H., Pollard, P. C., Moriarty, D. J. W., White, D. C. (1985). Quantitative determination of microbial activity and community nutritional status in estuarine sediments: evidence for a disturbance artifact. Can. J. Microbiol. 31: 493-498

Findlay, R. H., Trexler, M. B., Guckert, J. B., White, D. C. (1990a). Laboratory study of disturbance in marine sediments: response of a microbial community. Mar. Ecol. Prog. Ser. 62: 121-133

Findlay, R. H., Trexler, M. B., White, D. C. (1990b). Response of a benthic microbial community to biotic disturbance. Mar. Ecol. Prog. Ser. 62: 135-148

Folk, R. L. (1974). Petrology of sedimentary rocks. Hemphill, Austin, Texas

Galloway, R. W. (1982). Distribution and physiographic patterns of Australian mangroves. In: Clough, B. F. (ed.) Mangrove ecosystems of Australia. Australian National University Press, Canberra, p. 31-54

Gillan, F. T., Sandstrom, M. W. (1985). Microbial lipids from a nearshore sediment from Bowling Green Bay, North Queensland: the fatty acid composition of intact lipid fractions. Org. Geochem. 8: 321-328

Griffiths, R. P., Hayasaka, S. S., McNamara, T. M., Morita, R. Y. (1978), Relative microbial activity and bacterial con- 
centrations in water and sediment samples taken in the Beaufort Sea. Can. J. Microbiol. 24: 1217-1226

Hansen, J. A., Alongi, D. M., Moriarty, D. J. W., Pollard, P. C. (1987). The dynamics of benthic microbial communities at Davies Reef, central Great Barrier Reef. Coral Reefs 6: 63-70

Hobbie, J. E., Daley, R. J., Jasper, S. (1977). Use of Nuclepore filters for counting bacteria by fluorescence microscopy. Appl. environ. Microbiol. 33: 1225-1228

Hopkinson, C. S. (1985). Shallow water benthic and pelagic metabolism: evidence of heterotrophy in the nearshore Georgia Bight. Mar. Biol. 87: 19-32

Meyer-Reil, L. A. (1983). Benthic response to sedimentation events during autumn to spring at a shallow water station in the Western Kiel Bight. II. Analysis of benthic bacterial populations. Mar. Biol. 77: 247-256

Meyer-Reil, L. A. (1987). Seasonal and spatial distribution of extracellular enzymatic activities and microbial incorporation of dissolved organic substrates in marine sediments. Appl. environ. Microbiol. 53: 1748-1755

McIntyre, A. D. (1968). The meiofauna and macrofauna of some tropical beaches. J. Zool., Lond. 156: 377-392

McIntyre, A. D. (1969). Ecology of marine meiobenthos. Biol. Rev. 44: 245-290

Montagna, P. A., Coull, B. C., Herring, T. L., Dudley, B. W. (1983). The relationship between abundances of meiofauna and their suspected microbial food (diatoms and bacteria). Estuar. coc.st. Shelf Sci., 17: 381-394

Moore, H. B. (1972). Aspects of stress in the tropical marine environment. Adv, mar. Biol, 10: 217-269

Moriarty, D. J. W. (1986). Measurement of bacterial growth rates in aquatic systems from rates of nucleic acid synthesis, Adv, Microb. Ecol. 9: 245-292

Moriarty, D. J. W., Pollard, P. C. (1990). Effects of radioactive labelling of macromolecules, disturbance of bacteria and adsorption of thymidine to sediment on the determination of bacterial growth rates in sediment with tritiated thymidine. J. Microbiol. Meth. 11: 127-139

This article was submitted to the editor
Nair, S., Bharathi, P. A. L. (1980). Heterotrophic bacterial populations in tropical sandy beaches. Mah.-Bull. Nat. Inst. Oceanogr. 13: 261-267

Pollard, P. C. (1987). Dialysis: a simple method of separating labelled bacterial DNA and tritiated thymidine from aquatic sediments. J. microbiol, Meth. 7: 91-101

Pollard, P. C., Moriarty, D. J. W. (1984). Validity of the tritriated thymidine method for estimating bacterial growth rates: measurement of isotope dilution during DNA synthesis. Appl. environ. Microbiol, 48: 1076-1083

Raine, R. C. T., Patching, J. W. (1980). Aspects of carbon and nitrogen cycling in a shallow marine environment. J. exp. mar. Biol. Ecol. 47: 127-139

Revelante, N., Gilmartin, M. (1982). Dynamics of phytoplankton in the Great Barrier Reef Lagoon. J. Plankt. Res. 4: $47-76$

Robertson, A. I., Alongi, D. M., Daniel, P. A., Boto, K. G. (1988). How much mangrove detritus enters the Great Barrier Reef lagoon? Proc. 6th int. Coral Reef Symp. 2: 601-606

Sokal, R. R., Rohlf, F. J. (1969). Biometry, the principles and practice of statistics in biological research. W. H. Freeman, San Francisco

Thorson, G. (1957). Bottom communities (sublittoral or shallow shelf). Mem. Geol. Soc. Am. 67: 461-534

Tietjen, J. H. (1980). Microbial-meiofaunal interrelationships: a review. In: Colwell, R. R., Foster, J. (eds.) Aquatic microbial ecology. University of Maryland Press, College Park, p. $130-140$

Ullman, W. J., Sandstrom, M. W. (1987). Dissolved nutrient fluxes from the nearshore sediments of Bowling Green Bay, Central Great Barrier Reef Lagoon (Australia). Estuar. coast. Shelf Sci. 24: 289-303

Wolanski, E., Jones, M. (1981). Physical properties of Great Barrier Reef Lagoon waters near Townsville. I. Effects of Burdekin River floods, Aust. J. mar. Freshwat. Res. 32: 305-319

Manuscript first received: June 19, 1990

Revised version accepted: September 3, 1990 